\title{
The religious phenomenon of Juche ideology as a political tool
}

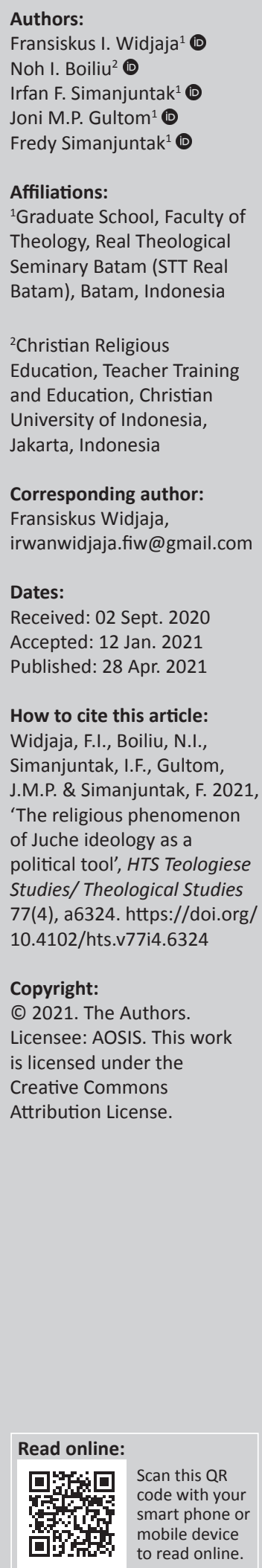

This study aims to determine the motive that led to the establishment of Juche by Kim Il Sung amidst the influence of communism and its transformation into religion in North Korea. North Korea is a communist country dictated by Kim Jong-Un of the Kim dynasty and known for its cruelty. The country underwent several changes from Marxism-Leninism to familism to determine its strength in Juche. This ideology that acts as a religion was influenced and strengthened Kim Jong Il to Kim Jong-Un and built by shifting the concept of marxismLeninism to construct a new understanding of Juche. It will be demonstrated that this ideology was influenced by Confucianism, Christianity, Nationalism, Chinese Communism, and Russian Communism. In the modern era, imperialism was used as an ideological tool to restrict backwardness. This theory allegedly helped Kim Il-Sung establish a unitary, oneperson rule over North Korea. 'It will be examined whether Juche ideology is a tool the state has used to convince people of their government. Pronouncements, an intentional religion in which the people were to believe that their Ruler (Kim Il Sung) was a supreme human or an ideology that morphed into a religion'. It will be demonstrated that, when they started honoring Kim as their god, no other religion was permitted.

Contribution: This research offers readers an understanding of the value of humanity in the binding ideology of Juche. However, the Juche Ideology can serve as a missiological bridge towards mission goals, which require the experience of spiritual, physical, and social liberation.

Keywords: ideology; Juche; North Korea; religion; political.

\section{Introduction}

Kim Jong-un, the current leader of North Korea, is the successor of Kim Jong II. 'Jong-Il pioneered and established the ideological foundation as a means of policy implementation and sustaining power' (Park 2014:1-14). It shows the concept of 'familism, socialism and religious politics' (Armstrong 2005:383-394). The family as a primary social unit is the starting point for emerging political figures, including 'religious leaders'. Armstrong's article reacts to Sergei Kurbanov's research on North Korea's Juche ideology: primitive communism or traditional thinking?

It will be examined whether Juche ideology is a tool the state has used to convince people of their government's pronouncements, an intentional religion in which the people were to believe that their Ruler (Kim Il-Sung) was a supreme human or an ideology that morphed into a religion (Bandow 2019).

The citizens were made to respect and accept these teachings.

North Korea is always in the global media, and it is often reported as a dangerous, provocative, irrational, poor and totalitarian country. Several dominant metaphors appeared (Dalton 2019) in the coverage. These framed North Korea as a military threat (conflict metaphor), unpredictable, irrational and ruthless (psychopathology metaphor), isolated and secretive (pariah metaphor) and a cruel dystopia (Orwellian metaphor) impoverished (basket-case metaphor).

However, it is one of the poorest nations that metaphorically isolate itself from the rest of the world. It is referred to as the Hermit Kingdom (Griffis 2009:66) derived from the Chosun Dynasty. To date, it is known as the 'Hermit kingdom', notably when it closed its borders to foreigners and restricted its citizens from travelling abroad since the Korean War in 1950.

Juche ideology is a form of idol worship. Juche ideology is a form of idol worship. In this case, Juche ideology has been developed into a world or a personal view of life. As Goudzwaard said in 
Ginkel (Ginkel 1982), when an individual or group of persons has chosen a particular goal and when that goal becomes the only way of giving meaning to life, then, said Goudzwaard, that individual or group is on the way to forming an ideology. He further links idolatry to come together with ideology when the goals set become so crucial that the means of attaining them become idols.

Foreigners had limited access to information apart from those communicated by the early missionaries. In 1884, the first Protestant missionary from the United States of America visited the country. Revivals began on the Korean peninsula in 1906 and climaxed in 1909 when the Pentecostal spiritual movement 'A million souls for Christ' occurred (Lamport 2018:431).

Widjaja visited Pyong Yang, capital of North Korea, from 29 October to 03 November 2018 to look into the social life context. A lot needs to be understood regarding this country.

North Korea is still governed by the legacies left by its founder Kim Il-Sung who died in 1994. Following the Juche philosophy, which is also signified in its meaning 'Ju' depicts owner, or lord whilst 'che' implies body, essence or existence, and nature. This meaning is similar to the basic philosophical principle usually expressed in Korea, which stated that 'man is the master of everything and decides everything' (Kurbanov 2019:296-305).

Furthermore, when the author and team travelled to North Korea, they saw several banners with a proverb, which stated that 'Kim Il-Sung lives forever. The citizens see Kim Il-Sung as a god. The recent inception of the former dictator's worship has become one of the world's acclaimed religions, with approximately 23 million followers. It is more famous than most renowned faiths globally, such as Judaism, Sikhism, Jainism, Bahaism and Zoroastrianism. However, according to Belke, Juche ideology is the tenth-largest religion that has not been studied from the missiological perspective (Belke 1999:1).

Subsequently, other religions are not permitted, except for the worship of Kim Il-Sung. Newbigin (Newbigin 1989:66) reported that 'throughout history, all religions globally have been developed in the tradition of sustainable, rational arguments. They have all attracted the professor's authority in the past'. It is suggested in the writings of Newbigin that an ideology can develop into a religion that the present author identifies with the Korean Confucian tradition. The author sees that it is an aspect of the North Korean pluralism reported by Newbigin (Newbigin 1989:1). 'In Western ideology, pluralism is considered an appropriate characteristic of a secular society that lacks an officially approved pattern of belief or behaviour.

Therefore, it is also presumed as a free society because accepted dogmas do not control it; rather, it is mainly characterised by an important spiritual being'. Widjaja (2019:591; cf. Widjaja \& Boiliu on a plurality [Widjaja \& Boiliu 2019]) stated that pluralism is a condition that encompasses a society that tolerates diversity. Korean culture has tended towards being mono-ideological because it always had a single ideology, Confucianism. Widjaja defined this new religion and the North Korean society as having a natural affinity towards communism.

\section{Research method}

The data collection technique is carried out in two ways: firstly, the literature study method searches for various literature and other credible sources related to the research topic directly in the Juche library. Secondly, by conducting interviews to gather information or perceptions from informants regarding the issue, the author wanted to research whilst travelling in North Korea. The historical and descriptive approach was applied in this study. The author visited the Juche Center located in Pyongyang from 30 October to 02 November 2018. Two persons accompanied the author during the trip: Ms. Kim, a young lady, as an interpreter and an old gentleman (67 years) as a tour guide. They are both interviewed and several individuals met at the centre (principles of Juche Center), and librarians were also interviewed regarding Juche ideology.

This research tries to describe the Juche ideology and the North Korean society's pluralistic conditions and examines the missiological paradigm contextualisation in their social culture. This research also interpreted the theological vocation of the church in a pluralistic world. Widjaja sees the pluralistic society of North Korea as a bridge for doing contextualised evangelistic task.

\section{Result and discussion}

In 1994 after Il-Sung's death, North Korea was hit by severe famine ; the successor Kim Jong-Il opened the United Nations (UN) and Non-Government organization (NGOs) borders assistance. At this point, foreigners realised they had a biased view of North Korean culture and religion. The puzzles concerning Kim Il-Sungism started to be understood (Lee 2018). The world could not develop a holistic picture because previous studies on North Korea did not approach Korean ideology from an ethnic position. We have been able to gain new insights from defectors who gave us a new understanding of Juche theology and its development, and its becoming a religion. However, the complete picture was not detected because ethnic approaches did not wholly analyse the pieces. The previous studies were carried out from the political perspective rather than a missiological concept. However, some defectors aided in understanding the Juche ideology and why it was developed as a North Korean religion. Hwang Jang-Yup, an engineer primarily responsible for crafting Juche, defected from North Korea in 1997 (Kihl \& Kim 2015:62). It gave foreigners an insight into Kim II Sungism that led to the factors that influenced Juche theology being identified. 


\section{Confucianism influence}

Kim Il-Sung was raised in a typical Korean family under the influence of Confucianism. Irrespective of the fact that most of them had survived under Shamanism's influence (belief in a supernatural being is the earliest form of religious practice). Shamans (Kim 1998:33) are healers or spiritual leaders believed to interact with the spirit world through altered states of consciousness such as trance. Consequently, when they are unconscious, their souls leave their bodies and travel beyond a spirit guide. They carry out various forms of healing, namely physical, psychological and spiritual.

Confucianism filled the Shamanism structured teaching gap, and it is the Chosun's leading religion (Young 2013:51-66). The Confucian philosophy was introduced in Korea 1600 years ago from China. Its originator Confucius lived from 551 $\mathrm{BC}$ to $479 \mathrm{BC}$, and the doctrines were humanistic and philosophical teachings concerning the importance of family and social harmony. It focused on the way of life (Lee 2018).

Confucius taught moral and political values to control the people authoritatively. Moreover, patriotism was also included. Besides, some other scholars added different ethics to the original philosophy, emphasising that a well-behaved lifestyle on earth leads to a better life after death. Finally, ancestral worship was included, and it was observed as a religion (Lee 2018).

In 1392, the Chosun Dynasty (Griffis 2009:73) replaced Buddhism, the Koryo Kingdom's recognised religion, with Confucianism, which forces people to obey their teachers, fathers and king. It consists of strict rules following maintaining a hierarchically structured society. The king rules with the monarchy and is above the law. Fathers were also the heads of household and their decisions are final. Under the influence of Confucianism, this patriarchal society maintains a strict structured order and does not allow individual family members' freedom. Women do not have a say in family matters; instead, they obey the men's rankings in the household. The eldest son is the only person who has authority over the house layout. The father's obligation and duty is to maintain power in a society influenced by Confucianism (Griffis 2009:73).

\section{Christianity influence}

Kim Il-Sung was born in 1912, 2 years after Japan annexed Korea (Kim 1992:17). His father, Kim Hyung-Jik, gained admission into Soong-Shil Junior High School in Pyongyang (Kim 1992:4), an academy established by missionaries in 1897 to educate and raise Christian leaders in Korea. Irrespective of the fact that Kim Hyung-Jik did not complete his education, Kim was enlightened, and the school broadened his worldview. Kim was fortunate to travel outside Korea with the help of the foreign Christian teachers. Kim Hyung-Jik became a nationalist and started fighting for Chosun's independence.
Kim Il-Sung's family migrated to China when Kim was aged 5 years because the Japanese police threatened his father because of the anti-Japanese movement's threats. Kim's father studied the Lenin Revolution in Russia and told Kim Il-Sung about it, hoping to influence Korea. (Kim 1992:79). Kim Il-Sung witnessed how his father fought the Japanese to regain their independence. Kim's father taught him the Christian faith values, thereby causing Kim to view the world's religious disposition. Numerous Christians influenced Kim's father because the Japanese had taken advantage of them for their worship of God. The father's patriotism led to the development of Christian social religion'. Although Kim Il-Sung reported in the memoir of his father that he was an atheist (Kim 1992:20). Kim Il-Sung also stated that his mother was only a churchgoer and not a born again Christian (Kim 1992:79). Although Kim Il-Sung had frequently attended a church at a young age, Kim categorically stated that they did not believe in Jesus as their saviour.

However, it is the reason the political system of the North Korean government resembles the order of the Presbyterian church, thereby providing evidence of the influence of Christianity on the life of Kim.

\section{Communism influence in China}

Kim Il-Sung returned to China at the age of 14 and was trained as an anti-Japanese guerrilla. In 1926 (Kim 1992:96), Kim learned to fight after studying Korean history. During this period, Kim studied Chinese communism and war strategies from militaristic organisations. Koreans allied with the Chinese revolutionary army to fight the Japanese who had invaded eastern China. Whilst in the camp, Kim started reading and studying Communism by Marx and Lenin, which was not included in the training curriculum (Belke 1999:171).

Kim formulated 'The Way of the Korean Revolution' on June 30, 1930, in China. Kim reported that 'the leaders' of the movement needed to be amongst the masses (people) to make them understand that they are fighting a political war, against the 'anti-Japanese struggle' (Belke 1999:170). Kim's approach of combining communism and religion led to the Juche being founded, which insisted that the state become autonomous without other countries' interference. Subsequently, Kim joined and participated in the antiJapanese guerrilla war in Manchu, China. Kim fought as a commander at Bo-Chun-Bo and Mu-San from 1937 to 1939, respectively. Kim was only 27 years old then, which led to the recognition by the Soviet Union as a 'general' that fought against the Japanese (Kim 2003:106).

\section{The influence of Russian communism}

The Korean peninsula is one of the oldest and most dangerous conflict-prone areas globally (Ponomareva \& Rudov 2015: 45-56). According to the biography, Kim stated the war's happenings in 1940 during the International Communist Party's Conference held by the Soviet Union. Kim was 
guaranteed the support of an organised and trained force to fight against the Japanese troops in Manchu, China. The Soviet Union needed someone to introduce Chosun in communist Russia, a satellite country. Kim was appointed as the commander of the Chosun People's Revolution and was given the southern camp (Kim 1992:71). Kim was assigned to combat Japanese expansion in the Khabarovsk region. In 1942, during the summer of 1942, China and the Soviet Army formed a joint force and attacked Japan.

Kim was an aggressive communist soldier and was favoured by Stalin. On 25 August 1945, the Soviet Union special forces entered Pyongyang City without resistance from the Japanese Army (Seth 2018:27). Kim was only 33 years old then. Kim gained power in North Korea because of the help of the Soviets and was surrounded by advisers from the Union (Belke 1999:171). On 25 August 1948, Kim was elected as the Prime Minister because of the influence of Marxist communism and the brutal application of Stalin's Soviet-style policies (Seth 2018:27). With the Soviet Union's military assistance, Kim invaded South Korea in 1950 over the 38th parallel line drawn at Potsdam, Germany, in 1945. Kim desired to bring the peninsula under communism. The war continued until the United States signed the Armistice agreement in collaboration with the United Nations on 27 July 1953.

\section{Formation of Juche ideology}

The dogma of Marxism-Leninism, without a doubt, was accepted as the law from 1945 to 1952 (Belke 1999:173). Kim focused on rebuilding the country destroyed by a war based on the Russian communist system. Furthermore, Kim broadened the teachings of Stalin's Communist-policies in the country.

After Stalin's death on 05 March 1953, Russia experienced chaos because of a lack of a strong leader. Stalin's death also led to specific political challenges in North Korea because they withdrew their support, and the Chinese sought to exercise control over the nation. Kim founded the Juche ideology in its embryo form as a means to justify a series of brutal cleansing to cut off excessive Soviet and Chinese influences and eliminate political rivals (Belke 1999:173). Kim (28 December 1955) stated that North Korea needs to become independent following the Juche ideology. Kim's speech was titled 'Eliminating Dogmatism and Formalism and Building Juche in Ideological Work'. The Workers' Party in North Korea started to develop this idea and new policies began to emerge. It is one of the most powerful ideologies that incite people's quest for independence and 'appeals to creativity at the highest level but a creativity that brings captivity and bondage' (Col 2:8):

See to it that no one takes you captive through philosophy and empty deception, according to the tradition of men, according to the elementary principles of the world, rather than according to Christ.

All those who desired to be independent united and cooperated with support from the communist manifesto and constitution (Kementerian Unifikasi Korsel, Institute for Military History dan Agency for KIA Recovery \& Identification di Kementerian Pertahanan Korea Selatan 2020).

It was reported that the country was under new communism different from Marx or Lenin's ideology. This unique development of combining a Marxist of Lenin's ideology with Confucianism led to Juche ideology, defended by Kim's dictatorship (Jang-yop 1999:127).

The principle 'Juche' considers the fact that generally humans are the driving force in history (Grzelczyk 2012:33-68) and 'are the master of their destiny'.

Kim Jong-Il joined the Communist Party after graduating from the university in 1964. Kim increasingly fought the struggle for the North Korean leader succession. It led to competitive personal deification in which Stalin was involved by supporting economic aid and rebuilding North Korea after war (Jang-yop 1999:1292).

In 1972, Kim Jong-Il conferred the Juche Tower and the new Doctrine on the father's 60th birthday.

Pyongyang stated that Juche is an ideology completely different from Marxism-Leninism. These changes were reflected in the constitution in 1974. The new form disclosed that the people supported their leaders.

Kim Il-Sung was seen as a god. It contradicts the statement made by Kim Il-Sung before joining Marxist communism.

'Religion is a superstitious belief, irrespective of whether an individual believes in Christianity or Buddhism.

Historically, religion has been dominated by the ruling class and is used as a tool to deceive, exploit and oppress people. Presently, imperialism has been used as an ideological tool to curb backwardness (Kim 2017:160).

Hwang stated that 'assuming the "Juche" doctrine is summarised in one sentence, it tends to be reported as the ruler (Kim Il-Sung) is the inviolable god who is in absolute control and conducts the affairs of the society because they are perceived as almighty (Jang-yop 1999:147). North Korea has a religion in which Kim Il-Sung is worshipped following the Juche.

\section{Juche culture}

The author's visit to North Korea could not produce an accurate missiological study because of its limited nature. The movement of foreigners and citizens is restricted in this nation. The author could not leave the hotel without an escort and could not visit many cities. People are not aware of each others' activities because freedom of movement is prohibited. 
Therefore, because of this fact, this study is based on the author's observations of Juche's religious view.

The restriction of movement has been instrumental in the formation of a Juche culture. It is the control of communication through the limiting of movement and access to technology that has entranced Juche culture (Güven 2019).

\section{Death of God}

The citizens were shocked when Kim Il-Sung died in 1994; some of them even fainted. Several of them cried for days because it was not the death of an ordinary person (Seth 2018:154). Incredibly, many North Koreans believed and hoped that Kim Il-Sung was an immortal being. From a foreigners' perspective, it is hard to believe that the people thought that Kim, a human was immortal. After Kim Il-Sung's death, Kim Jong-Il immediately made a banner that stated that 'Kim Il-Sung lives forever among them'. Kim Jong-Il led people to honour the father, Kim Il-Sung, under Confucian ancestor worship and spiritual being under the Juche ideology.

\section{Juche's religious practices}

Consequently, whenever foreigners visit North Korea and make inquiries on the definition of Juche, only a few people provide accurate answers, according to Juche's guide book (2008:17). They have been indoctrinated to act and dwell under the Juche ideology in which Kim Il-Sung teaches that 'Humans are the master of the universe and are in control of their destinies as well as the right to have it developed' (Juche Guideline 2008:15). 'From an atheist's point of view, man's absolute ability to control his destiny has replaced the belief in God's existence'. Lee (2018) testified as a defector after studying the Bible and having discovered God and wrote that Juche is a concept adopted from the Bible. It might be agreed on one hand because the Bible attributed a high value on human life. Yet, Christianity teaches that human life is subject to God's authority. Thus, a human being is God's appointed steward responsible for keeping God's commandment and glorifying God (Cho 2002).

Furthermore, Christianity rejects the concept of absolute human power. On the contrary, Christians are believed to live by imitating Christ, who, although in God's image, humbled and emptied himself to bring salvation and renewal to human life. So, there is quite a significant difference between Juche ideology and Christianity. Although North Koreans are not aware of this ideology's influences, they had been taught to observe Juche. They make individual life decisions without acknowledging God's existence, and they have a humanistic worldview as a result. Many North Koreans are not aware or have never heard of Christianity or that Jesus came to save humanity; however, they believe in Communist materialism and its evolution. North Korea built over 40000 statues of Kim Il-Sung in the country (Lee 2018). Married couples usually visit the statue to take pictures. It validates their marriage after the ceremony. They often see with flowers to honour their gods.
Every city centre has a Juche ideology study room and a temple to worship Kim Il-Sung. North Koreans enter this Hall in holiness, and people are prohibited from speaking out loud except to pay respect in the form of worship. People visit this place in holiness, communicate their desires and receive spiritual power.

\section{North Korea church}

In 1958, all the churches in North Korea were destroyed and believers eliminated by the communists during the antiintelligence movement. The remaining ones were underground and remained as universal, invisible churches (Lee 2018).

\section{Official church}

The communist even closed a church approved by the government in 1958 and reopened it in 1972 to show the world that there is religious freedom similar to South Korean Christianity.

\section{Underground church}

The exact number of underground believers in North Korea is unknown. However, 16984 martyrs have been recorded from 1945 to 2006. It shows the existence of underground churches in this nation (Lee 2018). It was discovered that approximately $66 \%$ of the martyrs were converted to Christianity before 1945, their parents influenced 20\%, 11\% reported that they were Christians and 2\% stated that they encountered God in China (Lee 2009).

\section{Juche as a political tool}

To establish Juche means 'to be revolutionised and reconstructed in the nation itself' (Lee 1997). It becomes the basis for the rise of 'totalitarianism' (Park 2008), in which the mechanism is to create figures as deified. In principle, 'politics uses religion or religion uses politics' (Linz 2004). The point is 'to create power as widely and as strong as possible' (Schafer 2004) 'as "dictator and fascism" (Gregor 2012) where "the principle of fascism is the state as religion" (Armstrong 2016). Juche is used as a political tool (religious politics) in North Korea. Historically, Juche was also rooted in Marxism, because for Khazanov, 'Marxism-Leninism as a secular religion' (Khazaniv 2008). Therefore, the theory that religion can be used as a political tool or politically using religion is correct, as is North Korea's case. Juche did not offer salvation such as religion in general, but Juche found it a political tool of totalitarianism. The indoctrination that has taken place in North Korea through the instrument of Juche ideology and it is a barrier that undermines the introduction of other ideologies and religion.

\section{Missiological perspective}

A missiological perspective on Juche opens a broad view of the universal value of human beings. Juche valued humans as the master of the universe and are in control of their destinies as well as the right to have it developed, but his deviation was the abuse of one person. This article also wants to show that 
the mission's purpose is to convey that all people experience liberation spiritually, physically and socially.

In the present context, the church cannot perform its mission because of the socio-political problems.

However, the task cannot be understood in the narrow sense of preaching the Gospel to North Korea's people.

This article encourages and voices that everyone has an equal position before God in the Christian mission perspective. The act of suppressing individual rights in North Korea is deviant. Therefore, the idea of 'individual equality' in Juche must be upheld (cf. Widjaja, Simanjuntak \& Boiliu 2020:189-193).

\section{Conclusion}

Juche's ideology was influenced by Confucianism, Christianity, Nationalism, Chinese and Russian communism. North Korean liberators modified Russian communism. Subsequently, Kim Jong-Il changed communism into a religion according to the Juche doctrine, making the people believe that Kim was immortal.

Kim Il-Sung initially opposed religion because Kim believed it is superstitious to either believe in Jesus or Buddhism. Historically, religion has been dominated by the ruling class and is used as a tool to deceive, exploit and oppress the people. In the modern era, imperialism was used as an ideological tool to restrict backwardness.

The North Koreans were made to worship Kim with Juche as the political philosophy of a ruling government. However, it was transformed into religion because the people believed that the ruler (Kim Il Sung) is not elected; instead, he is a supreme human.

Therefore, when the people started to honour Kim as their god, no other religion was permitted. It led to an increase in the persecution of underground churches because of various reasons. Generally, Marxist communism does not allow Christianity because the Christian faith does not support materialism adhered to by the communists. Lenin called it 'the opium of the masses', and it tends to destroy the society.

The author reported that there are similarities between Juche ideology and Confucianism. Initially, they started as philosophies, although later converted to religion for their selfish political reasons. Juche has become a major religious force that has manoeuvered North Korea to replace traditional Marxist communism.

\section{Acknowledgements}

The authors would like to thank Winson Simamora, Nelsong Sembiring, Wellhelem Manuhutu and Berliando Lumban
Toruan to accompany and help the author (Fransiskus Irwan Widjaja) in collecting the information to North Korea and for documentation and partner for discussion during their time in North Korea in 2018. The authors are grateful to Mr Noh I. Boiliu for editing and providing additional supporting articles. The authors are also thankful to Mr Irfan Feriando Simanjuntak for delivering the concept and required description and $\mathrm{Mr}$ Joni Manumpak Parulian Gultom for reviewing this article before its publication. The authors also thank Mr Fredy Simanjuntak for taking part in the sentence editing process.

\section{Competing interests}

The authors declare that they have no financial or personal relationships that may have inappropriately influenced them in writing this article.

\section{Authors' contributions}

All authors contributed equally to this research article.

\section{Funding information}

This research received no specific grant from any funding agency in the public, commercial or not-for-profit sectors.

\section{Data availability}

Data sharing is not applicable to this article as no new data were created or analysed in this study.

\section{Disclaimer}

The views and opinions expressed in this article are those of the authors and do not necessarily reflect the official policy or position of any affiliated agency of the authors.

\section{References}

Armstrong, C., 2016, 'Political religion', in P. Corner \& J.H. Lim (eds.), The Palgrave handbook of mass dictatorship, pp. 67-80, Foreign Languages Publishing House.

Armstrong, C.K., 2005, 'Familism, socialism, and political religion in North Korea', Totalitarian Movements and Political Religions 6(3), 383-394. https://doi. org/10.1080/14690760500317743

Belke, T., 1999, Juche: A Christian study of North Korea's state religion, Living Sacrifice Book Company.

Cho, E., 2002, 'The encounter between the Juche idea and Christianity', Mission Studies XIX(1), 1-37. https://doi.org/10.1163/157338302X00062

Dalton, B., 2019, 'Hermit kingdom, nuclear nation ... If the media keep calling North Korea names, it will only prolong the conflict', The Conversation.

Ginkel, A.V., 1982, 'Goudzwaard expose today's idol', Perspective (Institute for Christian Studies) 16(2), 1-4.

Gregor, A.J., 2012, Totalitarianism and political religion: An intellectual history, Stanford University Press.

Griffis, W.E., 2009, Corea, the hermit nation (1882), Cambridge Scholars Publishing.

Grzelczyk, V., 2012, 'In the name of the father, son, and grandson: Succession patterns and the Kim dynasty', The Journal of Northeast Asian History 9(2), 33-68.

GÜVEN, E., 2019, 'The Juche System and the DPR Korea Media as Official Mouthpiece of the Kim Family', Global Media Journal TR Edition 10(19), 194-215.

Jang-yop, H., 1999, I saw the truth of the history, Han-Yul.

Kementerian Unifikasi Korsel, Institute for Military History dan Agency for KIA Recovery \& Identification di Kementerian Pertahanan Korea Selatan, dan B.S.N.K., 2020, Indeologi 'Juche' (mandiri secara swasembada), Semenanjung Korea, A to Z.

Khazaniv, A.M., 2008, 'Marxism-Leninism as a secular religion', in R. Griffin, R. Mallett \& J. Tortorice (eds.), The sacred in twentieth century politics: Essays in honour of professor Stanley G. Payne, pp. 119-142, Palgrave Macmillan. 
Kihl, Y.W. \& Kim, H.N., 2015, North Korea: The politics of regime survival, 2nd edn., Routledge.

Kim, I.S., 1992, Kim II-Sung heads of state, Korea (North), biography: Korean resistance movements, 1905-1945, p. 3447, Foreign Languages Publishing House (English edn.).

Kim, K-U., 2003, Studies of North Korean political history (History of establishment), Sonin.

Kim, S., 2017, Authority and emotions: Kim Jong II and religious imagination in North Korean literature, Harvard.

Kim, T., 1998, Korean Shamanism: Muism, Jimoondang.

Kurbanov, S.O., 2019, 'North Korea's Juche ideology: Indigenous communism or traditional thought?', Critical Asian Studies 51(2), 296-305. https://doi.org/10.10 80/14672715.2019.1566750

Lamport, M.A., 2018, 'North Korea', in Encyclopedia of Christianity in the global south, 2nd edn., p. 1122, Rowman \& Littlefield, London.

Lee, G., 1997, 'The Political Philosophy of Juche', Stanford Journal of East Asian Affairs 3(1), 105-112.

Lee, P., 2009, Toward a missiological understanding of the persecuted church in North Korea, Fuller Theological Seminary.

Lee, P., 2018, Peeling the onion formation of North Korean Juche as a religion.

Linz, J.J., 2004, 'The religious use of politics and/or the political use of religion: Ersatz ideology versus Ersatz religion', in $\mathrm{H}$. Maier (ed.), Totalitarian movements and political religions, I, pp. 102-119, Routledge, Taylor, and Francis.
Newbigin, L., 1989, The Gospel in a pluralist society, Eerdmans Publishing Co.

Park, C.H., 2008, 'The traditional morality of totalitarianism - Analysis of Juche ideology through honoring parents', in Proceedings of the 52nd annual meeting of the ISSS-2008, pp. 1-11.

Park, Y.S., 2014, 'Policies and ideologies of the Kim Jong-un regime in North Korea: Theoretical implications', Asian Studies Review 38(1), 1-14. https://doi.org/10.10 80/10357823.2013.868864

Ponomareva, E. \& Rudov, G., 2015, 'Russia-North Korea: State of affairs and trends', Journal of Asian Public Policy 9(1), 45-56. https://doi.org/10.1080/17516234.201 5.1122716

Schafer, M., 2004, 'Luigi Sturzo as a theorist of totalitarianism', in H. Maier (ed.) Totalitarianism and political religions, I, pp. 21-30, Routledge, Taylor, and Francis.

Seth, M.J., 2018, North Korea: A history, Red Globe Press.

Widjaja, F.I., 2019, 'Pluralitas dan Tantangan Misi: Kerangka Konseptual untuk Pendidikan Agama Kristen dalam Masyarakat Majemuk', Pendidikan Agama Kristen Regula Fidei 4(1), 591. https://doi.org/10.33541/jrfvol1iss1pp115

Widjaja, F.I. \& Boiliu, N.I., 2019, Misi dan Pluralitas Keyakinan di Indonesia, Andi Offset.

Widjaja, F.I., Simanjuntak, F. \& Boiliu, N.I., 2020, 'Repositioning mission in postmodern culture', 414 (Iceshe 2019), pp. 189-193. https://doi.org/10.2991/assehr.k. 200311.038

Young, C., 2013, 'Into the sunset: Ch'ŏndogyo in North Korea, 1945-1950', Journal of Korean Religions 4(2), 51-66. https://doi.org/jkr.2013.0010 